Article

\title{
Productive and economic response to partial replacement of cracked maize ears with ground maize or molasses in supplements for dual- purpose cows
}

\author{
Isela G. Salas-Reyes ${ }^{\text {a }}$ \\ Carlos M. Arriaga-Jordán ${ }^{b}$ \\ Julieta G. Estrada-Flores ${ }^{b}$ \\ Anastacio García-Martínez ${ }^{\text {a }}$ \\ Rolando Rojo-Rubio ${ }^{\text {a }}$ \\ José F. Vázquez Armijo ${ }^{a}$ \\ Benito Albarrán-Portillo ${ }^{\text {a* }}$
}

a Universidad Autónoma del Estado de México. Centro Universitario UAEM. Temascaltepec. Km 67.5 Carretera Toluca-Tejupilco, Temascaltepec. 51300. Estado de México. México.

${ }^{\mathrm{b}}$ Universidad Autónoma del Estado de México. Instituto de Ciencias Agropecuarias y Rurales. Estado de México. México.

*Corresponding autor: balbarranp@ gmail.com

\begin{abstract}
:
The aim of the study was to assess the effect of partial replacement of cracked maize ears with ground maize (GM) or sugar cane molasses (SCM) in supplements for dual purpose cows. Eighteen (18) multiparous cows (414 $\pm 13 \mathrm{~kg}$ of body weight and $106 \pm 32 \mathrm{~d}$ in milk) were randomly assigned to the treatments. Treatments were as follows: 1) Control supplement (CS) which consisted of $87 \%$ of cracked maize ears (CME), $11 \%$ soybean meal, and 2\% urea; 2) Ground maize replacing 20\% of CME in CS (GMS); 3) Sugar cane molasses replacing $18 \%$ of $\mathrm{CME}$ in the CS (MOS). Each cow received $5 \mathrm{~kg} / \mathrm{d}$ of
\end{abstract}


supplement DM, whereas their calves received $1.8 \mathrm{~kg} / \mathrm{d}$ DM of the CS. The experiment lasted eleven weeks, and data were recorded once at the end of every week. Data were analysed using a linear mixed model as a completely randomized design. Net profit from milk and beef due to supplements were estimated using the partial budget approach. There were no differences $(P>0.05)$ between treatments on milk composition, body conditions score, nor daily weight gain of cows and calves. However, compared to GM, CS shown greater $(9.0 \%, P<0.05)$ dry matter intake and SCM shown greater milk yield $(18.6 \%$, $P<0.05)$. Partial replacement of cracked maize ears with ground maize or sugar cane molasses, in supplements for dual purpose cows, did not affected animal productive response. However, considered the combined net profit margins (milk and calves), SCM got an average of $9 \%$ higher profits compared of the rest of supplements.

Key words: Milk, Beef, Brown Swiss, Tropical Grasses, Energy supplementation.

Received: 05/08/2017

Accepted: 30/04/2018

\section{Introduction}

Dual-purpose (DP) bovine production, in tropical regions of Mexico and Latin America, rely on the use of local resources like grasses, shrubs and trees under extensive management. In the south west of the State of Mexico as well as in most tropical regions of México, cattle feed exclusively on forages under extensive grazing during the rainy season. During the dry season (December to May), the availability and nutritional quality of forages decreases considerably. To minimize the impact of the low forage availability and to the diminished quality of forages, farmers supplement their cattle with variable amounts of supplement (5 to $9 \mathrm{~kg} \mathrm{DM} /$ cow/d) $)^{(1)}$.

Farmers' decision on the amount of supplement offered to each cow, and the time to start supplementation during the dry season, depends on the availability of forage on pastures. The second half of the dry period (March to May) is the most critical for farmers, since forage in pastures becomes scarce, so that farmers use supplements to sustain animal production $^{(1,2)}$.

Metabolizable energy has been reported as one of the main constrains for cattle production under tropical conditions due to the low nutritional value of forages (due mainly to high fibre content) ${ }^{(3)}$. 
Supplements represent between 50 to $70 \%$ of milk and beef production costs. Due to supplementation, milk production costs increase $22 \%$ in the dry season, in comparison to the rainy season, reducing the already slim profit margins ${ }^{(1,2)}$.

In order to keep supplement costs as low as possible, harvested maize ears produced in the farm are cracked instead of being ground, in order to reduce processing cost. However, total digestibility of cracked maize ears is lower $(87.6 \%)$, compared with ground maize $(91.7 \%)^{(4)}$. Frequently, un-degraded large particles of maize appear in faeces representing a waste and inefficient use of this resource.

Maize starch is the most common source of energy for dairy cattle, that degrades between 4 to $6.4 \% / \mathrm{h}$. Carbohydrate sources with faster degradation rates than maize may improve ruminal conditions, resulting in better animal productive response to supplementation ${ }^{(5)}$.

Sugar cane molasses is a readily source of energy, that has been used in supplements for cattle feeding on low quality grasses in tropical regions ${ }^{(6,7,8)}$. However, despite availability and relatively low cost, farmers in the study region do not incorporate this resource in their cattle supplements.

The inclusion of sugar cane molasses under in vitro studies improves fibre digestibility of a combination of star grass (Cynodon nlemfuensis) and Leucaena leucocephala; whereas the inclusion of maize grain increased in vitro volatile fatty acids production ${ }^{(9)}$. Furthermore, addition of sugar cane molasses to supplements based on maize silage, improved growing rates of heifers under tropical conditions, reducing production costs at the same time ${ }^{(6)}$.

The aim of this experiment was to evaluate the productive and economic response of partial replacement of cracked maize ears (control supplement) with ground maize $(20 \%$ inclusion) (GM), or sugar cane molasses (18\% inclusion) (SCM), in supplements offered to grazing dual purpose Brow Swiss cows during the dry season in a subtropical region of Mexico.

\section{Material and methods}

\section{Area description}

The study was performed in a commercial dual purpose farm in the State of Mexico, at $19^{\circ} 04$ ' $48^{\prime \prime} \mathrm{N}$ and $100^{\circ} 13^{\prime} 18^{\prime} \mathrm{W}$, and an altitude of $1,470 \mathrm{~m}$. Climate is subtropical (warm sub-humid), with a mean annual temperature of $23^{\circ} \mathrm{C}$, and $1,115 \mathrm{~mm}$ mean annual rainfall. 


\section{Experimental farm}

The participating farm is of typical characteristics of DP of the region. Resources, management and socioeconomic characteristics have been described ${ }^{(1)}$. Briefly, the farm produces milk all year round, and milk and calves sales represent 42 and $44 \%$ of annual incomes, respectively. Daily milk incomes cover daily expenses of farm operation, and the economic needs of the farming family. Calves are sold at 18 mo old, usually by the end of the rainy season. Farm land extension is 100 ha and the perimeter fenced, with no subdivisions, where cattle graze all year round. Usually, around 35 milking cows and their calves plus a sire are kept as a single herd, whereas replacements, are kept on a different location. Cattle feed exclusively on forages during the rainy season, receiving only mineral supplementation. During the dry season, cows are supplemented with a mixture of cracked maize, and soybean meal ( $\sim 5 \mathrm{~kg} / \mathrm{cow} / \mathrm{d} \mathrm{DM})$.

\section{Animals and management}

Eighteen (18) multiparous Brown Swiss cows (414 $\pm 13 \mathrm{~kg}$ weight and $106 \pm 32 \mathrm{~d}$ in milk) were randomly allocated to one of three treatments (six cows per treatment).

Experimental cows grazed with the rest of the herd. Stocking rate was 0.25 animal units (AU) per ha. Cows had access to ad libitum water and minerals. Milking of cows was manually from 0700 to $0900 \mathrm{~h}$ once a day. Before milking, the calf was allowed to suckle for few seconds the first milk for let-down, and then tied to the cow's neck until the end of milking. Afterwards, calves suckled the residual milk and remained with their dam in grazing areas until $1400 \mathrm{~h}$.

After been separated from their dams, calves remained in a different paddock until the next morning, where they grazed on a pasture of similar characteristics as the cows. Calves received $1.8 \mathrm{~kg} \mathrm{DM} / \mathrm{d}$ of control supplement (CS) (Table 1), and had access to water and a mineral mix ad libitum. 
Table 1: Ingredients and chemical composition of control (CS), ground maize (GM), and sugar cane molasses (SCM) supplements (g/kg DM)

\begin{tabular}{lcccc}
\hline & CS & GM & SCM & SEM \\
\hline & Ingredient & composition: & & \\
Cracked maize ears & 866 & 696 & 693 & \\
Soybean meal & 111 & 81 & 107 & \\
Ground maize & & 200 & & \\
Molasses & & & 177 & \\
Urea & 23 & 23 & 23 & \\
& Chemical composition: & & \\
Dry matter & 873 & 870 & 849 & 4.1 \\
Crude protein & 124 & 113 & 119 & 14.4 \\
Neutral detergent fibre & 379 & 218 & 214 & 2.7 \\
Acid detergent fibre & 55.7 & 63.0 & 48.9 & 0.6 \\
Lignin & 11.0 & 11.5 & 11.4 & 8.5 \\
Dry matter digestibility & 903 & 908 & 940 & 5.2 \\
Organic matter & 895 & 901 & 933 & 11.3 \\
digestibility & 792 & 715 & 809 & 3.2 \\
NDF digestibility & 14.1 & 14.1 & 14.6 & 16.1 \\
Metabolizable energy, & & & & \\
MJ/kg DM & 59.8 & 46.5 & 68.1 & \\
& & 0.128 & 0.153 & \\
Solubles (a) & 256.8 & 274.2 & 255.7 & \\
Solubles rate (0-1) & 0.062 & 0.067 & 0.065 & \\
Insoluble (b) & 5.8 & 5.5 & 4.2 & \\
Insolubles rate (0-1) & & & \\
Lag (h) & & & \\
\hline
\end{tabular}

From a previous study (unpublished), calves consumed on average $3.0 \mathrm{~kg}$ of milk estimated by weight differences before suckling ( $0900 \mathrm{~h}$ milking) and after removal from their dams (1400 h).

The management of cows and calves during the experiment was minimal in order to avoid stress in the animals, and not to interfere with the farmer's daily activities. Therefore, cows and calves were weighted once a week.

\section{Treatments}

The control supplement (CS) was based on cracked maize ears (CME) (husk, kernels and cob) $(86.6 \%)$, complemented with soybean meal $(11.1 \%)$ and urea $(2.3 \%)$. In the first experimental supplement, $20 \%$ of ground maize grain partially replaced cracked maize ears, to form the ground maize supplement (GM). For the second experimental 
supplement, $18 \%$ of molasses replaced the same proportion of cracked ear maize (SCM). Table 1 shows the ingredients and chemical composition of supplements.

Experimental cows individually received their assigned supplement ( $5 \mathrm{~kg}$ of DM/cow/d) while milking, in a cloth bag tied to their neck. All cows consumed the supplement entirely.

The experiment started on February $19^{\text {th }}$ and ended on May $8^{\text {th }}$ of 2015 . Previous to the start, cows spent one week as adaptation period to the supplements. Then, the experiment proceeded for the next $11 \mathrm{wk}$ (experimental periods).

\section{Milk yield and composition}

Milk yield was recorded on the last day of every week. After milking, cows and calves were weighted. Body condition score (BCS) of cows was determined on a 1 to 5 score scale. Milk composition (fat, protein and lactose $\mathrm{g} / \mathrm{kg}$ ) was determined within $2 \mathrm{~h}$ after milking on recording day with a portable ultra-sound milk analyser. Milk urea nitrogen (MUN) was subsequently determined in the laboratory by enzymatic colorimetry.

\section{Feed sampling and chemical analysis}

Pasture variables were determined every other week (1, 3, 5, 7, 9 and 11). Available herbage mass (AHM) (kg DM ha/d), was determined by placing six quadrants $\left(0.25 \mathrm{~m}^{2}\right)$, adjacent to a patch where the cows were grazing at the sampling time. Herbage mass (HM) inside the quadrants was cut to ground level with shears to determine AHM in grazing areas. From the quadrants, a $25 \mathrm{~g}$ sample was separated into live and dead matter, and each was weighed.

Determined pasture variables (kg DM/ha) were: available herbage mass (AHM), and its corresponding amounts of leaf (LA), stem (SA), dead matter (DMA), and live matter (LMA).

Green matter was considered live matter, and non-green matter was considered dead matter. LA and SA were estimated from the $25 \mathrm{~g}$ samples harvested from each quadrant by separating leaves from stems and weighing them separately. Finally, a composite sample from the six quadrants $(100 \mathrm{~g})$ per week was taken to determine chemical composition of pastures.

Supplements were sampled on two consecutive days at the end of every week, to determine chemical composition of a composite sample. Feed samples were dried at 
$60{ }^{\circ} \mathrm{C}$ to constant weight to determine DM. They were also analysed for ash, crude protein (CP) by the micro Kjeldahl method ${ }^{(10)}$. Neutral detergent fibre (NDF), acid detergent fibre (ADF) and acid detergent lignin (ADL) using the Ankom method ${ }^{(11)}$. The ME of supplements and pasture was estimated using the OMd values from in vitro gas production, using the following equation ${ }^{(12)}$ :

$$
\mathrm{ME}(\mathrm{MJ} / \mathrm{kg} \mathrm{DM})=(\mathrm{OMd})(0.0157)
$$

Where:

$\mathrm{ME}=$ metabolizable energy $(\mathrm{MJ} / \mathrm{kg} \mathrm{DM})$;

OMd digestibility of organic matter (g/kg DM).

The in vitro dry matter digestibility (DMd), organic matter digestibility (OMd), and NDF digestibility (NDFd) were determined using the in vitro gas production technique. Degradation fractions $a, b$ and $L$ of herbage were estimated according to the following equation $^{(13)}$.

$$
y=A\{1-\exp [-b(t-T)-c(\sqrt{t}-\sqrt{T})]\}
$$

Where:

$\mathbf{y}=$ cumulative gas production $(\mathrm{mL})$,

$\mathbf{t}=$ is the incubation time in hours,

$\mathbf{A}=$ is the asymptote of the total gas produce $(\mathrm{mL} / \mathrm{g} \mathrm{DM})$,

$\mathbf{b}=$ is the constant of gas produced per hour,

$\mathbf{c}=$ is a constant, and

$\mathbf{T}=$ is a discrete lag time in hours in that microorganisms colonize the substrate and star the fermentation.

The degradation fraction rate $(\mu)$ was calculated using the following equation ${ }^{(13)}$ :

$$
\mu=\mathrm{b}+\mu=\mathrm{b}+\frac{\mathrm{c}}{2 \sqrt{ } t}, t \geq T
$$

\section{Herbage dry matter intake}

Cow's herbage DMI was estimated indirectly from animal performance, taking calculations for energy requirements of milking cows from and estimated ME content of feeds from chemical analysis ${ }^{(14)}$. 
Herbage dry matter intake $(\mathrm{kg} /$ day $)=\frac{\text { MEm }+ \text { MEml }+ \text { MEL }+ \text { SupME }}{\text { Herbage ME }}$

Where:

MEm, MEml and MELw are the estimated ME requirements for maintenance, milk yield and live weight change, respectively.

SupME is the ME provided by the supplement (MJ/kg DM).

Herbage $\mathrm{ME}$ is the estimated $\mathrm{ME}$ concentration of herbage samples. The ME concentrations of supplements and pasture were calculated using OMd results from in vitro gas production ${ }^{(13)}$ :

$$
M E\left(\frac{M J}{k g} D M\right)=(O M d)(0.0157)
$$

\section{Economic analysis}

The economic analysis was performed using the partial budget approach ${ }^{(15)}$, to determine the economic profits from the use of supplements, exclusively for milk and beef (i.e. $\mathrm{kg}$ of weaned calves). Economic analysis results are expressed in US dollars.

\section{Statistical analyses}

The data were analysed using the MIXED procedure of SAS $9.0^{(16)}$ for a completely randomized experimental design, with cow as a random effect to account for repeated measurements on the same animal throughout the experiment.

The model used was:

where:

$$
\mathrm{y}_{i j k}=\mu+\tau_{i}+\delta_{i j}+\mathrm{t}_{k}+(\tau * \mathrm{t})_{i k}+\varepsilon_{i j k}
$$

$\mathbf{y}_{i j k}=$ dependent variable,

$\boldsymbol{\mu}=$ overall mean,

$\boldsymbol{\tau}_{i}=$ fixed effect of treatment ( $i=1,2$ and 3$)$,

$\mathbf{t}_{k}=$ fixed effect of $\mathrm{Wk}(k=1,2 \ldots 11)$,

$(\tau * \mathbf{t})_{i k}=$ fixed effect of interaction between treatment $i$ and $\mathrm{Wk} k$,

$\boldsymbol{\delta}_{i j}=$ random effect of cow $j$ within each treatment and,

$\boldsymbol{\varepsilon}_{i j k}=$ random error term. 
Least squares means and standard errors for fixed effects were obtained and used for multiple mean comparisons. Significant differences between treatments were declared when $P<0.05$.

\section{Results}

Table 2 shows the chemical composition of pasture herbage as well as in vitro gas production parameters. Crude protein average was $58 \mathrm{~g} / \mathrm{kg}$ DM, having maximum values in wk3 and wk4 (70 and $75 \mathrm{~g} / \mathrm{kg} \mathrm{DM}$, respectively). Dry matter digestibility (DMd) and estimated metabolizable energy (ME) had the highest values in wk 4 and wk 5 (620 and $606 \mathrm{~g} / \mathrm{kg} \mathrm{DM}$, and 9.6 and $9.4 \mathrm{MJ} / \mathrm{kg} \mathrm{DM}$, respectively).

Table 2: Herbage chemical characteristics $(\mathrm{g} / \mathrm{kg})$ and gas production curve parameters

\begin{tabular}{lcccccccc}
\hline Experimental week & $\mathbf{1}$ & $\mathbf{3}$ & $\mathbf{5}$ & $\mathbf{7}$ & $\mathbf{9}$ & $\mathbf{1 1}$ & Mean & SD \\
\hline Dry matter & 701 & 675 & 648 & 623 & 694 & 613 & 651 & 36.8 \\
Crude protein & 50 & 75 & 70 & 53 & 46 & 50 & 58 & 12.1 \\
Neutral detergent fibre & 716 & 704 & 706 & 703 & 738 & 796 & 728 & 36.2 \\
Acid detergent fibre & 371 & 367 & 360 & 369 & 401 & 424 & 380 & 25.0 \\
Acid detergent lignin & 14 & 14 & 15 & 17 & 14 & 16 & 15 & 1.3 \\
Dry matter digestibility & 559 & 580 & 620 & 606 & 555 & 497 & 570 & 43.7 \\
Organic matter digestibility & 552 & 572 & 612 & 599 & 548 & 490 & 564 & 43.5 \\
NDFd & 489 & 501 & 523 & 560 & 526 & 423 & 517 & 46.4 \\
ME, MJ/kg DM & 8.7 & 9.0 & 9.6 & 9.4 & 8.6 & 7.7 & 8.9 & 0.7 \\
& & & & & & & & \\
b & 200 & 198 & 209 & 213 & 181 & 160 & & \\
C & 0.0 & 0.031 & 0.033 & 0.032 & 0.034 & 0.039 & & \\
L & 32 & & & & & & & \\
\hline
\end{tabular}

The asymptotic gas production (b) (mL/g DM), had the highest values in wk 4 and wk 5 . The rate of gas production (c) showed the highest values in wk 6 (0.034) and wk 7 (0.039), whereas from wk 1 to wk 5 the rate remained constant $\sim 0.032 / \mathrm{h}$. Initial lag time before gas production begins (L) had the lowest value in wk1 (4.4), while from wk 2 to wk 7 values remained close to 5.2 .

Average NHA was $11(\mathrm{~kg} / \mathrm{ha} / \mathrm{d})$, whereas AHM was 1,932 (kg/ha DM). Pasture morphological composition is shown in Figure 1. Green pasture represented $58 \%$ of AHM, with and increasing trend towards the end of the study, due to some light rains; whereas leaf represented $38 \%$ of the AHM. Cynodon plectostachyus was the predominant 
grass representing $92 \%$ of the botanical composition; while Paspalum notatum and Paspalum convexum represented 5 and $3 \%$, respectively.

Figure 1: Available herbage mass (AHM) (kg/ha DM), morphological composition $(\mathrm{kg} / \mathrm{ha} \mathrm{DM})$ throughout experimental weeks

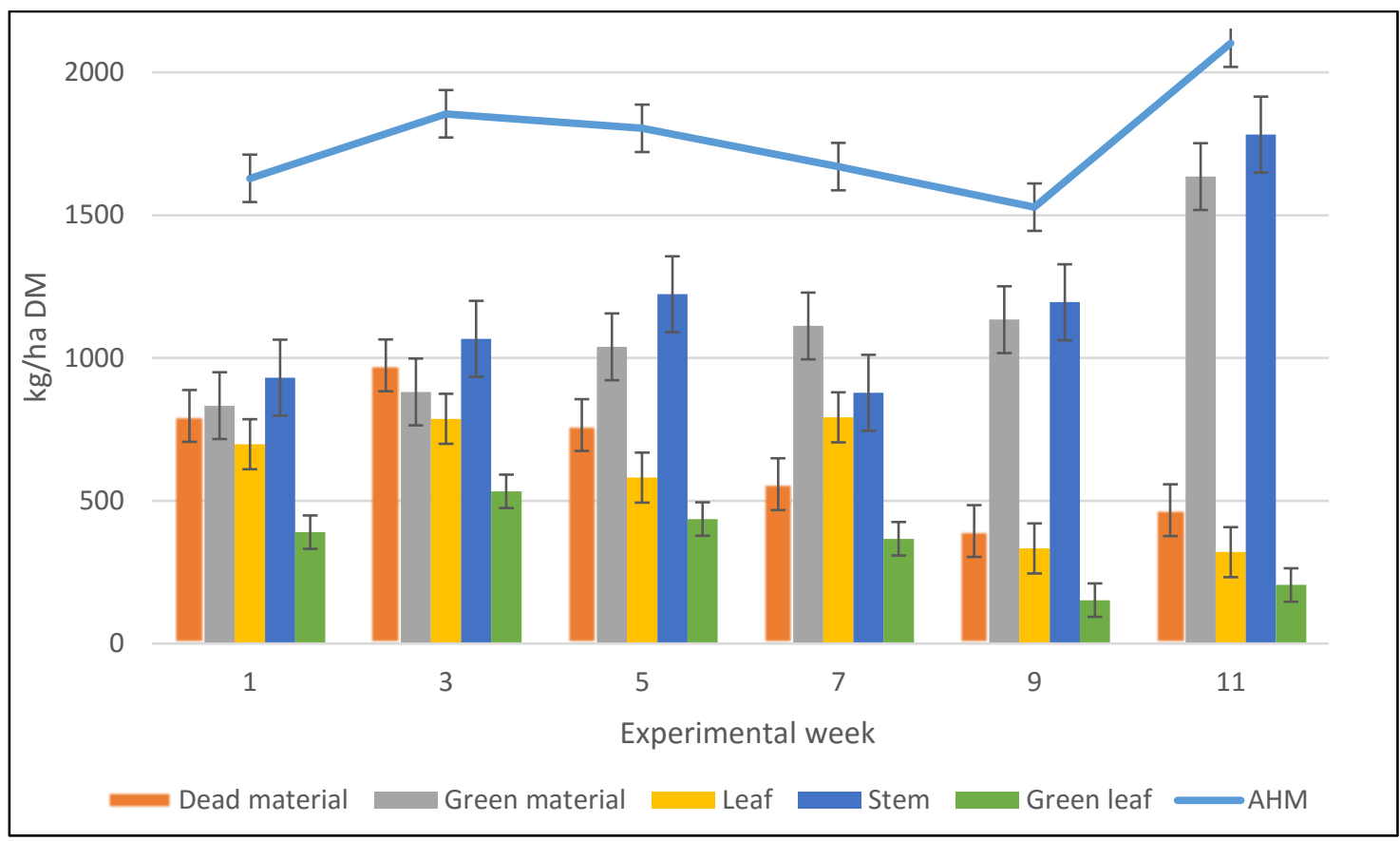

Table 1 shows ingredients and chemical composition of supplements. Average DM was $864 \mathrm{~g} / \mathrm{kg}$. Crude protein contents were 124 (CS), 113 (GM) and, 119 (SCM) g/kg DM. Neutral detergent fibre of CS was $43 \%$ higher $(379 \mathrm{~g} / \mathrm{kg} \mathrm{DM})$ than experimental supplements (218 and $214 \mathrm{~g} / \mathrm{kg} \mathrm{DM}$ for GM and SCM, respectively).

Molasses inclusion increased values for dry mater digestibility (DMd), organic matter digestibility (OMd) and neutral detergent fibre digestibility (NDFd), as well as estimated metabolizable energy (MJ/kg DM), compared with CS and GM. SCM water soluble content represented by the $a$ fraction produced higher gas volume (68.1), than CS (59.8) and GM (46.5) (Table 1). Soluble fermentation rate of CS was lower (0.098), than GM and SCM (0.128 and 0.153, respectively). Insolubles (b), which is the insoluble but potentially fermentable material was higher for GM (274.2), than CS (256.8) and SCM (255.7). The lag phase was shorter for MOS (4.2 h), intermediate for GM (5.5 h) and longer for CS $(5.8 \mathrm{~h})$.

Table 3 shows animal productive response variables. There were no significant differences due to treatments, with the exception of DMI and milk yield $(P<0.01)$. The effect of week was highly significant $(P<0.01)$ for all variables. 
Table 3: Least squares means of animal response variables due to control supplement (CS), ground maize supplement (GM) and, sugar cane molasses supplement (SCM) on dual-purpose lactating cows during dry season

\begin{tabular}{lcccc}
\hline & CS & GM & SCM & SEM \\
\hline Dry matter intake, kg/d & $12.2^{\mathrm{a}}$ & $11.1^{\mathrm{b}}$ & $11.7^{\mathrm{ab}}$ & 0.27 \\
Milk, kg/d & $6.2^{\mathrm{ab}}$ & $5.7^{\mathrm{a}}$ & $7.0^{\mathrm{b}}$ & 0.31 \\
Fat, g/kg & 33.8 & 34.6 & 33.2 & 2.1 \\
Protein, g/kg & 30.5 & 30.5 & 30.6 & 0.19 \\
Lactose, g/kg & 42.2 & 43.1 & 42.7 & 0.43 \\
Milk urea nitrogen, mg/dL & 8.0 & 7.5 & 7.5 & 0.28 \\
Cow weight, kg & 430 & 406 & 430 & 16.9 \\
Cow weight gain, kg/d & 0.283 & 0.136 & 0.281 & 0.13 \\
Body condition score, 1-5 & 1.5 & 1.5 & 1.5 & 0.03 \\
Calves daily weight gain, kg/d & 0.68 & 0.71 & 0.73 & 0.07 \\
\hline
\end{tabular}

${ }^{a, b, c}$ Means within a row with different superscript are significantly different $(P<0.05)$.

Dry matter intake $(\mathrm{kg} / \mathrm{cow} / \mathrm{d})$ of CS was statistically not different $(P>0.05)$ from SCM $(12.2$ and $11.7 \mathrm{~kg} / \mathrm{d}$, respectively), but significantly different $(P<0.05)$ from GM $(11.1$ $\mathrm{kg} / \mathrm{d})$; whereas GM and SCM were not different from each other $(P>0.05)$.

Milk yield was statistically similar between CS and SCM with 6.2 and $7 \mathrm{~kg} / \mathrm{cow} / \mathrm{d}$; whereas GM $(5.7 \mathrm{~kg})$ was different from SCM but similar to CS. There were no differences $(P>0.05)$ for the rest of the response variables. Fat, protein and lactose mean contents were 33.9, 30.5 and 42.7 (g/kg), respectively. Mean milk urea nitrogen (MUN) was $7.7(\mathrm{mg} / \mathrm{dL})$.

Live-weight was not different between treatments (430, 406 and $430 \mathrm{~kg} / \mathrm{cow}$, for CS, GM and SCM, respectively). Cows given CS, GM and SCM had similar $(P>0.05)$ daily weight gains of $0.283,0.136$ and $0.281(\mathrm{~kg} / \mathrm{d})$, respectively. The average body condition score (BCS) was 1.5 points. Calves mean weight gain was 0.7 (kg/d) (Table 3$)$.

Table 4 shows the partial budget analysis of milk and beef (weaned calves) due to supplements. Molasses supplement had a higher production cost (i.e. total supplement cost), but had better economic returns (i.e. total milk profit margin). 
Table 4: Milk and beef production cost due to supplements: control (CS), ground maize (GM) and sugar cane molasses (SCM)

\begin{tabular}{|c|c|c|c|c|c|}
\hline \multirow{11}{*}{ 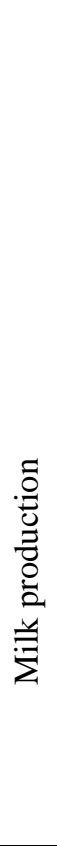 } & Item & CS & GM & SCM & Mean \\
\hline & Total supplement, kg/treatment & 2,730 & 2,730 & 2,730 & 2,730 \\
\hline & $\begin{array}{l}\text { Supplement cost, } \$ / \mathrm{kg} \mathrm{DM} \\
\%^{\mp}\end{array}$ & $\begin{array}{l}0.24 \\
-0.05\end{array}$ & $\begin{array}{l}0.25 \\
-0.01\end{array}$ & $\begin{array}{c}0.27 \\
+0.07\end{array}$ & 0.25 \\
\hline & $\begin{array}{l}\text { Total supplement cost, } \$ \\
\%^{\mp}\end{array}$ & $\begin{array}{c}655 \\
-0.01\end{array}$ & $\begin{array}{c}677 \\
+0.02\end{array}$ & $\begin{array}{c}660 \\
-0.01\end{array}$ & 664 \\
\hline & $\begin{array}{l}\text { Total milk yield, } \mathrm{kg} / \text { treatment } \\
\%^{\mathrm{F}}\end{array}$ & $\begin{array}{r}3,260 \\
-0.02\end{array}$ & $\begin{array}{r}3,041 \\
-0.09\end{array}$ & $\begin{array}{l}3,713 \\
+0.11\end{array}$ & 3,338 \\
\hline & Milk selling price, $\$ / \mathrm{kg}$ & 0.39 & 0.39 & 0.39 & 0.39 \\
\hline & $\begin{array}{l}\text { Milk sales incomes, } \$ \\
\%^{\mathrm{F}}\end{array}$ & $\begin{array}{l}1,269 \\
-0.02\end{array}$ & $\begin{array}{r}1,184 \\
-0.09\end{array}$ & $\begin{array}{l}1,446 \\
+0.11\end{array}$ & 1,300 \\
\hline & $\begin{array}{l}\text { Milk production cost, } \$ / \mathrm{kg} \\
\%^{\mp}\end{array}$ & $\begin{array}{r}0.20 \\
-0.03\end{array}$ & $\begin{array}{c}0.22 \\
+0.06\end{array}$ & $\begin{array}{r}0.20 \\
-0.03\end{array}$ & 0.21 \\
\hline & $\begin{array}{l}\text { Milk's profit margin, } \$ / \mathrm{kg} \\
\%^{\mp}\end{array}$ & $\begin{array}{c}0.19 \\
+0.04\end{array}$ & $\begin{array}{l}0.17 \\
-0.07\end{array}$ & 0.190 .04 & 0.18 \\
\hline & $\begin{array}{l}\text { Total milk's profit margin, } \$ / \text { treatment } \\
\%^{\mp}\end{array}$ & $\begin{array}{l}613 \\
0.0\end{array}$ & $\begin{array}{l}507 \\
-0.17\end{array}$ & $\begin{array}{l}721 \\
+0.17\end{array}$ & 614 \\
\hline & $\begin{array}{l}\text { Total milk's profit margin, } \$ / \text { cow } \\
\%^{\mp}\end{array}$ & $\begin{array}{l}102 \\
0.0\end{array}$ & $\begin{array}{c}85 \\
-0.17 \\
\end{array}$ & $\begin{array}{r}120 \\
+0.17 \\
\end{array}$ & 102 \\
\hline \multirow{10}{*}{ 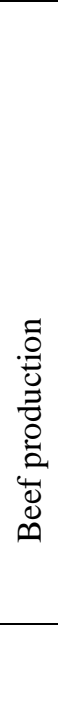 } & Supplement, kg/treatment & 601 & 601 & 601 & 601 \\
\hline & Supplement cost, $\$ / \mathrm{kg}$ & 0.24 & 0.24 & 0.24 & 0.24 \\
\hline & Total supplement cost, $\$$ & 144 & 144 & 144 & 144 \\
\hline & $\begin{array}{l}\text { Beef produce, } \mathrm{kg} / \text { treatment } \\
\%^{\mathrm{F}}\end{array}$ & $\begin{array}{c}371 \\
-0.04\end{array}$ & $\begin{array}{l}388 \\
0.0\end{array}$ & $\begin{array}{c}399 \\
+0.03\end{array}$ & 386 \\
\hline & Beef selling price, $\$ / \mathrm{kg}$ & 3.24 & 3.24 & 3.24 & 3.24 \\
\hline & $\begin{array}{l}\text { Beef incomes, \$/treatment } \\
\%^{\mathrm{F}}\end{array}$ & $\begin{array}{l}1,205 \\
-0.04\end{array}$ & $\begin{array}{c}1,258 \\
0.0\end{array}$ & $\begin{array}{l}1,293 \\
+0.03\end{array}$ & 1,252 \\
\hline & Beef production cost, $\$ / \mathrm{kg}$ & 0.34 & 0.34 & 0.34 & 0.34 \\
\hline & $\begin{array}{l}\text { Beef margin profit, } \$ / \text { treatment } \\
\%^{\mp}\end{array}$ & $\begin{array}{l}1,064 \\
-0.04\end{array}$ & $\begin{array}{l}1,118 \\
+0.01\end{array}$ & $\begin{array}{l}1,153 \\
+0.04\end{array}$ & 1,112 \\
\hline & $\begin{array}{l}\text { Beef margin profit, } \$ / \text { calf } \\
\%^{\mathrm{F}}\end{array}$ & $\begin{array}{c}177 \\
-0.04\end{array}$ & $\begin{array}{c}186 \\
+0.01\end{array}$ & $\begin{array}{r}192 \\
+0.04\end{array}$ & 185 \\
\hline & $\begin{array}{l}\text { Total net margin profit, }(\$)(\text { milk + beef) } \\
\%^{\mp}\end{array}$ & $\begin{array}{l}1,678 \\
-0.03\end{array}$ & $\begin{array}{l}1,625 \\
-0.06\end{array}$ & $\begin{array}{l}1,874 \\
+0.09\end{array}$ & 1,726 \\
\hline
\end{tabular}

$\%^{\mathrm{F}}=$ Difference in relation to mean.

Beef production ( $\mathrm{kg} /$ treatment as weaned calves) for SCM was higher (399 $\mathrm{kg}$ ) than CS and GM (371 and $388 \mathrm{~kg}$, respectively); resulting in higher beef incomes and profit margins. GM was second best for both indicators.

Overall, SCM was the treatment with higher total net profit margin from milk plus beef with $\$ 1,874(P<0.01)$; whereas CS came second $(\$ 1,678)$ and, GM generated the lowest total net profit margin with $\$ 1,625$. 


\section{Discussion}

The AHM in grazing areas remained low but constant in the grazing areas. The low but constant forage production during the experiment in spite of dry conditions could be due to water filtered to pastures from a stream that runs across the study area. This may explain in part the constant green material in grazing areas from wk1 to wk9; whereas the sharp increment was due to unusual rain at the end of the study.

In spite of these, the chemical composition of pasture across the experiment was low in terms of CP, DMd, and estimated ME. Similar chemical and agronomic characteristics of pastures dominated by Cynodon plectostachyus, from a nearby location to this study have been reported ${ }^{(17,18)}$.

Molasses inclusion improved in vitro degradability of the supplement given by the fractions $a$ and $b$, resulting in $0.5 \mathrm{MJ}$ of estimated ME more than CS and GM. This improvement could have had a positive impact on forage digestibility, by improving the ruminal environment due to the supply of readily available energy, which could have increased dry matter intake (additive effect), as demonstrated in previous studies ${ }^{(19,20,21)}$.

The second best supplement was CS, according to soluble fraction $a$. Better degradation kinetics were expected in the GM than in the CS, since a small particle size of maize grain increases starch digestibility (high soluble fraction) ${ }^{(22)}$. However, CS had a higher soluble (a) fraction, higher insoluble (potentially degradable " $b$ ") and higher insoluble fermentation rate, than GM. These could be due to higher proportion of husk and cob material in CS, which have a greater potential degradability, compared with GM.

The low milk production response of cows on GM was unexpected, since ground maize has been reported to yield more energy in rumen in the form of propionate production. Rumen propionate production has been reported as the main driver of milk in lactating dairy cows ${ }^{(4)}$.

One possible explanation to the low milk production response could be related to the fact that GM had about $20 \%$ less soybean than the other two supplements. Low rumen degradable protein has been related to lower NDF digestibility ${ }^{(23,24)}$.

Furthermore, under low grass quality conditions like in this experiment, sugar cane molasses supplemented with urea, could be a better alternative than ground maize as a source of energy, since sugars are more rapidly fermented in the rumen than the starch from maize, allowing a readily supply of energy to rumen microbes. This may explain the higher soluble fraction and shorter lag phase of $\mathrm{SCM}^{(25)}$.

Milk yields and milk composition in this study were lower than yields of Holstein and Brown Swiss x Zebu cows ${ }^{(26,27)}$. However, cows in both studies lost weight $(\sim 40 \mathrm{~kg}$ ) and BCS, attributed to insufficient nutrients provided by the supplements; contrary to weight gained by the cows in this experiment $(\sim 0.233 \mathrm{~kg} / \mathrm{d})$. 
In this study, treatments did not affect milk composition (i.e. fat, protein or lactose); contrary to this, reports show significant differences in protein yield $(\mathrm{kg} / \mathrm{d})$ due to a reduction in maize grain particle size that increased starch fermentation, resulting on higher propionate concentration in rumen ${ }^{(23)}$.

Despite cows did gain weight due to supplements (average $0.233 \mathrm{~kg} / \mathrm{d}$ ), body condition score remained unchanged throughout the experiment ( 1.5). Dual purpose cows under typical management do not receive enough energy supplies, resulting in small cow size, and limited dry matter intake capacity limiting milk yields. To overcome this situation, it has been proposed supplementation of good quality tropical grasses $(0.6$ to $4.4 \mathrm{~kg} / \mathrm{d})$, and supplements (between 4.0 and $5.0 \mathrm{~kg} / \mathrm{d}$ ), all year round. By doing this, cows will likely be on a better body condition score, (positive energy balance), particularly during critical periods like early lactation, resulting on higher milk yields ${ }^{(28)}$.

It is important to note that the weather conditions during the dry season were atypical so the economic analysis should be taken with caution. From the economic point of view, molasses inclusion in the supplement increased profits from milk and beef. The small milk yield difference between these two treatments made a significant economic difference in milk and beef profit margin ${ }^{(29)}$.

Combined net profit margins from milk and beef (weaned calves) were around $9 \%$ higher for SCM compared to CS and GM. Molasses has been reported as an energy supplement that results in better milk and beef revenues ${ }^{(29,30)}$. However, these effects do not always happen. In situations when molasses is of high cost, its inclusion in dairy cow supplements represented a loss of revenue due to the small milk response ${ }^{(31)}$.

Farms in the study region cannot adopt any kind of forage conservation due to the steep conditions of pastures, besides the increased cost due to labour and machinery. Therefore, molasses inclusion in supplements during the dry season could be a supplementation alternative to sustain animal production performance, when forages are limited and of low quality.

\section{Conclusions and implications}

Partial replacement of cracked maize ears with sugar cane molasses, in supplements for grazing Brown Swiss dual purpose cows during the dry season, significantly increased milk yields over a supplement with ground maize. There were no differences in other animal productive response variables. Combined net profit margins (milk and calf sales) were on average $9 \%$ higher when including sugar cane molasses in supplements. 


\section{Acknowledgments}

For the financial support of the Consejo Nacional de Ciencia y Tecnología (CONACYT) of Mexico and to the Universidad Autónoma del Estado de México (UAEMEX). Gratitude is also expressed for the funding of this research through grants 1003/2012RCA (UAEMEX) and 129449 CB-2009 (CONACYT).

\section{Literature cited:}

1. Albarrán-Portillo B, Rebollar-Rebollar S, García-Martínez A, Rojo-Rubio R, AvilésNova F, Arriaga-Jordán, CM. Socioeconomic and productive characterization of dual-purpose farms oriented to milk production in a subtropical region of Mexico. Trop Anim Health Prod 2015;44(3):519-523. doi:10.1007/s11250-014-0753-8.

2. Salas-Reyes IG, Arriaga-Jordán CM, Rebollar-Rebollar S, García-Martínez A, Albarrán-Portillo B. Assessment of the sustainability of dual-purpose farms by the IDEA method in the subtropical area of central Mexico. Trop Anim Health Prod 2015;47(6):1187-1194. DOI 10.1007/s11250-015-0846-z.

3. Absalón-Medina VA, Blake RW, Gene Fox D, Juárez-Lagunes EG, Nicholson FC, Canudas-Lara EG. Limitations and potentials of dual-purpose cows herds in central coastal Veracruz, Mexico. Trop Anim Health Prod 2011;44(6):1131-1142. doi:10.1007/s11250-011-0049-1.

4. Owens FN, Zinn RA, Kim YK. Limits to starch digestion in the ruminant small intestine. J Anim Sci 1986;63(5):1634-1648.doi:10.2527/jas1986.6351634x.

5. Gehman AM, Bertrand JA, Jenkins TC, Pinkerton BW. The effect of carbohydrate source on nitrogen capture in dairy cows on pasture. J Dairy Sci 2006;89(7):26592667.

6. Vélez-Terranova M, Sánchez-Guerrero H, Duran Castro CV. Evaluación de la suplementación energética durante el crecimiento de novillas lecheras de reemplazo utilizando el modelo CNCPS. Trop Subtropical Agroecosys 2014;17(1):143-154.

7. Granzin BC, Dryden G McL. Monensin supplementation of lactating cows fed tropical grasses and cane molasses or grain. Anim Feed Sci Tech 2005;120: 1-16.

8. Hunter RA, Kennedy PM. Effects of increasing rates of molasses supplementation and forages quality on the productivity of steers. Anim Prod Sci 2016;56:871-881. http://dx.doi.org/10.1071/AN14846. 
9. Estrada-Liévano JM, Sandoval-Castro CA, Ramírez-Avilés L, Capetillo-Leal CM. In vitro fermentation efficiency of mixtures of Cynodon nlemfuensis, Leucaena leucocephala and two energy sources (maize or sugar cane molasses). Trop Subtropical Agroecosys 2009;10(3):497-503.

10. AOAC, Official Methods for Analysis. Association of Official Analytical Chemists 1990, Arlington, VA, USA.

11. Van Soest PJ, Robertson JB, Lewis BA. Methods for dietary fiber, neutral detergent fiber, and non-starch polysaccharides in relation to animal nutrition. J Dairy Sci 1991;74(10):3583-97.

12. AFRC (Agricultural and Food Research Council). An advisory manual prepared by the AFRC Technical Committee on Responses to Nutrients. Wallingford: CAB International. 1993.

13. Mauricio MR, Mould FL, Dhanoa MS, Owen E, Channa K, Theodorou MK. A semiautomated in vitro gas production technique for ruminant feedstuff evaluation. Anim Feed Sci Tech 1999;79(4):321-330.

14. Baker RD. Estimating herbage intake from animal performance. In: Leaver, JD editor. Herbage intake handbook. Hurley: British Grassland Society;1982:77-93.

15. Espinoza-Ortega A, Espinosa-Ayala E, Bastida-López J, Castañeda-Martínez T, Arriaga-Jordán CM. Small-Scale dairy farming in the highlands of central Mexico: technical, economic and social aspects and their impact on poverty. Exp Agr 2007;43:241-256.

16. SAS Institute. SAS User's guide. Statistics, Version 9 ed. SAS Inst., Inc., Cary, NC. 2002.

17. López-González F, Estrada-Flores JG, Avilés-Nova F, Yong-Angel G, HernándezMorales P, Martínez-Loperena R, et al. Agronomic evaluation and chemical composition of african star grass (Cynodon plectostachyus) in the southern region of the state of Mexico. Trop Subtropical Agroecosys 2010;12(1):1-9.

18. López-González F, Sánchez-Valdés JJ, Castelán-Ortega OA, Albarrán-Portillo B, Estrada-Flores JG. Agronomic and nutritional characteristics of three grass species in the southern region of Mexico. Indian J Anim Sci 2015;85(3):271-274.

19. Morales JL, Van Horn HH, Moore JE. Dietary interaction of cane molasses with source of roughage: intake and lactation effects. J Dairy Sci 1989;72(9):2331-2338.

20. Petty SR, Poppi DP. The live weight gain response of heifers to supplements of molasses or maize while grazing irrigated Leucaena leucocephala/Digitaria eriantha pastures in north-west Australia. Anim Prod Sci 2012;52:619-623. http://dx.doi.org/10.1071/AN11242. 
21. Tuyen DV, Tolosa XM, Poppi DP, McLennan SR. Effect of varying the proportion of molasses in the diet on intake, digestion and microbial protein production by steers. Anim Prod Sci 2014;55:17-26. http://dx.doi.org/10.1071/AN13225.

22. Rémond D, Cabrera-Estrada JI, Champon M, Chauveau B, Coudure R, Poncet C. Effect of corn particle size on site and extent of starch digestion in lactating dairy cows. J Dairy Sci 2004;87(5):1389-1399.

23. San Emeterio F, Reis RB, Campos WE, Satter LD. Effect of coarse or fine grinding on utilization of dry or ensiled corn by lactating dairy cows. J Dairy Sci 2000;83(12):2839-2848.

24. Barros T, Quaassdorff MA, Aguerre MJ, Olmos CJJ, Bertics SJ, Crump PM, Wattiaux MA. Effects of dietary crude protein concentration on late-lactation dairy cow performance and indicators of nitrogen utilization. J Dairy Sci 2017;100:54345448.

25. Baurhoo A, Mustafa A. Effect of molasses supplementation on performance of lactating cows fed high-alfalfa silage diets. J Dairy Sci 2014;97(2):2072-1076.

26. Tinoco-Magaña JC, Aguilar-Pérez CF, Delgado-Leon R, Magaña-Monforte JG, Ku Vera JC, Herrera-Camacho J. Effects of energy supplementation on productivity of dual-purpose cows grazing in a silvopastoral system in the tropics. Trop Anim Health Prod 2012;44(5):1073-1078. doi:10.1007/s11250-011-0042-8.

27. Peniche-González IN, González-López ZU, Aguilar-Pérez CF, Ku-Vera JC, AyalaBurgos AJ, Solorio-Sánchez FJ. Milk production and reproduction of dual-purpose cows with a restricted concentrate allowance and access to an association of Leucaena leucocephala and Cynodon nlemfuensis. J App Anim Res 2014;42(3):345351.

28. Absalón-Medina VA, Blake RW, Gene Fox D, Juárez-Lagunes EG, Nicholson FC, Canudas-Lara EG, et al. Limitations and potentials of dual-purpose cows herds in central coastal Veracruz, Mexico. Trop Anim Health Prod 2011;44(6):1131-1142. doi:10.1007/s11250-011-0049-1.

29. Salvador-Loreto I, Arriaga-Jordán CM, Estrada-Flores JG, Vicente-Mainar F, García-Martínez A, Albarrán-Portillo B. Molasses supplementation for dual-purpose cows during the dry season in subtropical Mexico. Trop Anim Health Prod 2016;48(3):643-648. doi:10.1007/s11250-016-1012-y.

30. Jiménez-Ferrer G, Mendoza-Martínez G, Soto-Pinto L, Alayón-Gamboa A. Evaluation of local energy sources in milk production in a tropical silvopastoral system with Erythrina poeppigiana. Trop Anim Health Prod 2015;47(5):903-908. doi:10.1007/s11250-015-0806-7. 
31. Katongole CB, Kabirizi JM, Nanyeenya WN, Kigongo J, Nviiri G. Milk yields response of cows supplemented with sorghum stover and Tithonia diversifolia leaf hay diets during the dry season in northern Uganda. Trop Anim Health Prod 2016;48(7):1463-1469. doi:10.1007/s11250-016-1119-1. 